UDC: $395: 172.16$

\title{
ON HOSPITALITY (AFTER THE CRISIS)
}

\author{
Marin Beroš, $\mathrm{PhD}$ \\ marin.beros@gmail.com
}

\begin{abstract}
The global COVID-19 pandemic will affect our lives in many different aspects, of which the societal changes will be the ones hardest to predict or to alleviate. The focus of this paper will be on the idea of hospitality which will certainly come into question after the age of quarantine, social distancing and closed state borders passes. By providing historical overview and referencing authors such as Immanuel Kant, Jacques Derrida and Seyla Benhabib, the connection between the ideas of hospitality and cosmopolitanism will be examined. Consequently, the main aim of the paper will be to ascertain if we can still support the idea of the law of unconditional hospitality that cosmopolitans endorse, or has our current situation of global pandemic changed the situation so drastically that the conditional laws of hospitality are truly the best we can hope for.
\end{abstract}

Keywords: hospitality, cosmopolitanism, Kant, Derrida, Benhabib

\section{Introduction}

It seems strange, and probably unnecessary, in this time of forced social isolation to think about such a concept as hospitality. Actually, nothing could be further from the truth, as the times of crisis do not only call for action, but they also demand space for a reflection. Even though the crisis is still not completely over, it is beneficial to try to predict where "the road might take us next" - to assess the possible threats to society and our lives in general, as well as possible positive outcomes. My modest contribution to that endeavour is to inspire reflection in our time of imposed social distancing on the concept of hospitality, and how that concept could change when the global pandemic finally subsides. In that regard, we should probably start with the explanation of what hospitality is (at least up until now) and what are its historical roots. Furthermore, this short paper will make connections between closely related ideas of hospitality and cosmopolitanism, by referencing the philosophers such as Immanuel Kant, Seyla Benhabib and Jacques Derrida and their thoughts on the subject. In the end, their opinions will be surmised to provide a sort of a guidance for the time that is ahead of us, for the time of a "new normal", after the pandemic subsides.

Oxford English Dictionary defines hospitality as "the friendly and generous reception and entertainment of guests, visitors or strangers". ${ }^{1}$ As definitions go, this

${ }^{1} \mathrm{https} / / /$ www.lexico.com/en/definition/hospitality (accessed on 15.6.2020.) 
one is quite correct, but it is also quite strict and one-dimensional. It hardly indicates why the issue of hospitality has achieved such importance in our globalized world. Several reasons are involved. The first one is that hospitality has become a global business model, as worldwide travel and tourism are highly dependent on it. The second reason are migrations. Weather they are economic or humanitarian, legal or illegal, they raise the questions of excepting "the other into our home". And the third reason, which is in part provoked by the questions raised by the second one, there is a quite significant amount of scholarly discussion on the concept of hospitality, especially in recent political philosophy, to which we will turn later.

Our story on hospitality could probably start with the observation that Aristotle had made long time ago that human is by its nature a social animal. ${ }^{2}$ Which means that we, as a single human being, are "unfinished", our full potential can only be achieved by living in a society. Or as Aristotle claims "One who is incapable of sharing, or who is in need of nothing through being self-sufficient is no part of a city, and so is either a beast or a god." ${ }^{\prime 3}$ But society did not form completed, it had not appeared from thin air by pure chance, a twist of fate, or by an accident. In its formation there were a lot of concessions between different groups organized according to the types of life that humans lead, which could be roughly described as sedentary and migratory groups. And from those concessions that prevented the hostilities between the "farmers" and the "herders" had developed a whole set of customs that surround and enhance our inherent human gregariousness. Of these early customs, the one we probably know most about is Ancient Greek xenia, as we have plenty of its examples in both of Homer's epics.

\section{Xenia - ritualised friendship}

What were the specifics of the custom? Xenia was in general understood as generosity and courtesy shown to the travellers from the homeowner. Of course, this duty was reciprocal. Hosts needed to provide their guests with a bath, food, drink, gifts and even a safe escort to their next destination. It was considered rude to ask guests questions, even about their identity, before their immediate needs have been met. Guests on the other hand were required to bring gifts, be courteous to the host and provide the stories of their travels and news from the other parts of the world. Also, they were expected to return the hospitality to their hosts if they ever visited their homes. Considering the gifts, it was important that the exchange was of consummate value and that the return gift was offered immediately. Therefore, it is important to note that this was not a trade or barter, the exchange of gifts had more of a symbolic value, as it represented a token of a friendship which would ideally last for a long period of time, even through several generations.

\footnotetext{
2 Aristotle; Politics, University of Chicago Press, 2013.

3 Ibid, 1253a
} 
To understand why this custom was so well respected, it should be known that in Ancient Greece all strangers, without any exception, had a right to hospitality which was protected by Zeus, who in this role was also known as Zeus Xenios. For that reason, the violation of the duties of hospitality provoked his wrath. In Greek mythology there is even a reoccurring theme called theoxenia - stories in which humans show their virtue by helping unknown strangers, who are deities in disguise. Eventually, humans get rewarded for their observance of customs proscribed by gods. In its essence, theoxenia are cautionary tales which warn that any guest should be treated as potential divinity and that violation of the duties of hospitality provoked the punishment of gods. Turning to the "Iliad", now it becomes understandable why the abduction of one person could have "launched a thousand ships" and incite a tenyear war. The Achaeans had no other option than to avenge this transgression, as it was an insult to Zeus and his authority.

But, as the historian Gabriel Herman notices, xenia (which he translates as "guest friendship") is a custom that was respected only in the higher classes of Hellenic society, and especially during the Homeric times. ${ }^{4}$ With the rise of polis as a political institution other types of connections such as the ones towards compatriots emerged and "guest-friendship" became viewed as something inappropriate, or even in some circumstances (such as during the war between city states) treacherous. He confirms this change by quoting two passages, one from "Iliad" in which encounter in the field of battle by the Diomedes and Glaukos ends when they discover they are bonded through the xenia of their grandfathers; and the other is account from Xenophon in which Spartan king Agesilaos is reproached by the Persian satrap Pharnabazos for his attack because they were bound by the ties of hospitality - and yet Agesailaos disclaimed all personal responsibility and pleaded force majeure. ${ }^{5}$ Through this second example it is evident that the war between states disrupts connections made by xenia. Obligations to our compatriots and states now carry more weight than to our "guest-friends".

\section{Historical connection between the concepts}

It also should be highlighted that the concept of hospitality shares ancient ties with cosmopolitanism. Both concepts are transgressive, the duties they proscribe go over the boundaries of existing political communities. Adherents of both concepts do not consider loyalty to any particular political community, whether it is a community of birth or one of choice, to be their primary - they owe higher loyalty to the more universal community of all human beings. Regarding the cosmopolitanism, it should be noted that the very idea owes its origin to Cynic Diogenes of Sinope, who first

\footnotetext{
${ }^{4}$ Herman, G.; Ritualised Friendship \& the Greek City, Cambridge University Press, 1987.

5 Ibid. p. 1
} 
claimed "I am cosmopolitan". ${ }^{6}$ Although this determination was primarily negative in the sense that he did not declare it with the intention of becoming the first citizen of the world but to express disagreement with the laws of the ancient poleis, the Stoic school had taken his initial idea and turned it into a full concept. All people are morally equal owing to human ability of the use of reason, through which we recognize and respect the natural law that pervades the cosmos. The consequence of this Stoic viewpoint was that all people participated in reason and therefore should be respected equally, which was a position that was not easily defended in the ancient world of slaves and their masters. Through time, these teachings came into contact with Jewish mystical tradition, and their merging had a profound influence on the shaping of a new religion - Christianity. From these basic components arose the concept of human dignity, that is, the recognition and appreciation of the divine in every human being. In turn, the pursuit of equality and justice that permeates Christianity influenced the theory of natural law, which had a significant impact on the shaping as well as the recognition of basic human rights in the twentieth century.

This initial development of the idea of cosmopolitanism was followed by the period of "obscurity" of the theme, which with some exceptions lasted until the $18^{\text {th }}$ century, when interest in a number of "eternal peace" projects appeared. The most famous of these projects is certainly Kant's 'Perpetual Peace", but he also addressed the cosmopolitanism in the essay "Idea for a Universal History with a Cosmopolitan Purpose", as well as in certain parts of "Metaphysics of Morals". In an effort to prevent the Hobbesian natural state of relations between states, Kant used an already existing cosmopolitan ethical ideal to shape a new form of social contract at the interstate level. In order to achieve this ideal, it was necessary to envisage a new type of law, which Kant calls cosmopolitan law. It is important to note that unlike the area of international law that includes the rights of states in their legal relations with each other, i.e. legal obligations based on agreements and customs, the area of cosmopolitan law includes the rights of states and individuals in their legal relations with each other under cosmopolitan law.

Therefore, in 'Perpetual Peace" Kant offers six preliminary articles that aspire to reduce the possibility of war but taken on their own they cannot establish a lasting peace; and three definitive articles, which in turn lead to a lasting peace. These three definitive articles propose that every country should have a republican constitution, that every country should participate in the foedus pacificum (league of peace) and that cosmopolitan right based on universal hospitality must be instituted. The alliance of states that Kant proposes should be a voluntary coalition, which main purpose is securing world peace, that is, in turn, beneficial for the realization of all inherent human capabilities.

For our current topic, the third definitive article of "Perpetual Peace" is most important - "Cosmopolitan right shall be limited to the conditions of universal

${ }^{6}$ Diogenes Laertius; Lives of Eminent Philosophers, Oxford University Press, 2018., VI 63 
hospitality". 7 In Kant's opinion, hospitality and cosmopolitanism are deeply interlinked. Universal hospitality is defined as a right to visit foreign territories and to be welcomed in them, because "all men are entitled to present themselves in the society of others by virtue of their right to communal possession of the earth's surface". ${ }^{8}$ As our Earth is a globe of a finite shape, we must learn to live side by side as "no-one originally has any greater right than anyone else to occupy any particular portion of the earth". 9 Therefore, no one can legitimately appropriate the aforementioned surface and withhold the access to another.

But this right to universal hospitality is also conditioned upon the guest behaving in peaceful manner. In that regard, cosmopolitan right is understood as a right to access foreign territory. A citizen of one state can try to establish connections with other people, and no state can prohibit foreign citizens from traveling there. It is also limited to the offer of starting a trade, not as a right to demand actual trade. On the other hand, settlement in a foreign land is a completely different matter. Kant is extremely critical of the European colonization of countries already inhabited by the other people. He condemns the acts of oppression and exploitation of the natives on the ground of inequality in relations and allows settlement on their lands only through a non-coercive conscientious contract. He defends this claim with the view that even land that seems empty can be used by shepherds or hunters and cannot be occupied without their consent. Whatever were the limitations he had appointed to the right of hospitality, Kant has through the three definitive articles presented in "Perpetual Peace" articulated the principles of a different cosmopolitanism, which according to Seyla Benhabib recognizes that "individual is not only a moral being who is a member of a universal moral community but is also a person entitled a certain status in a world civil society." ${ }^{10}$

\section{Importance of hospitality to the modern cosmopolitanism}

In more recent times we also find authors who continuing Kant's insights connect the ideas of hospitality with cosmopolitanism. Aforementioned Seyla Benhabib is one of the philosophers who has had a significant influence on the development of recent cosmopolitan theory. She sees cosmopolitanism primarily as a project of mediation between the universalism of ethical norms and the particularism of national legal systems. In this realization of universal ethical norms, she considers the project of human rights decisive. In their examination, Benhabib relies heavily on Kant's understanding of cosmopolitanism as a right to hospitality. But as the political surroundings in which we live are much different than the ones at the start of

\footnotetext{
${ }^{7}$ Kant, I.; Political Writings, Cambridge University Press, 1991., p. 105

8 Ibid. p. 106

9 Ibid. p. 106

10 Benhabib, S.; Another Cosmopolitanism, Oxford University Press, 2006. p. 149.
} 
the $19^{\text {th }}$ century, Benhabib turns to Hannah Arendt who "After Kant... turned to the ambiguous legacy of cosmopolitan law, and... dissected the paradoxes at the heart of the territorially based sovereign state system." 11

Benhabib frequently uses the Hannah Arendt's "the right to have rights" phrase, which she introduced in her seminal work "The Origins of Totalitarianism". ${ }^{12}$ Arendt considered that the main cause for the rise of totalitarianism was a dissolution of nation-state system in Europe during the two world wars - totalitarian disregard for human life started when millions of human beings were turned stateless, which denied them "the right to have rights". Benhabib in her work reformulates this understanding of "the right to have rights" from its close relation to the right of membership in the political community, into a concept understood as a requirement for every human person to be recognized as a moral being worthy of equal care and of equal rights to protection as a legal person from his or her political community, as well as all the world's communities. ${ }^{13}$ As the globalization processes have weakened the state sovereignty, which in turn had the effect of diminished civil rights of citizens living in those states, cosmopolitanism of our own times must also come through changes. Therefore, Benhabib holds that the right to hospitality should not only apply in terms of a visit, as Kant understood it, but in certain cases should also apply to a longterm settlement. That is, according to her account, states of our own time also have duties to displaced persons and refugees, and they are significantly different from obligations to the visitors and immigrants.

Benhabib also notes that Universal Declaration of Human Rights, our main tenet and the greatest accomplishment of the doctrine of human rights, recognizes the right to freedom across the boundaries - a right to emigrate - that is to leave a country, but not a right to immigrate, a right to enter a country. "The Universal Declaration is silent on states' obligations to grant entry to immigrants, to uphold the right of asylum, and to permit citizenship to residents and denizens." ${ }^{14}$ Despite the crossborder, cosmopolitan character of human rights, the Universal Declaration is still mindful of the sovereignty of individual states. Benhabib therefore disappointedly concludes that "series of internal contradictions between universal human rights and territorial sovereignty are built into the logic of the most comprehensive international law document in the world". ${ }^{15}$

Jacques Derrida is another philosopher who in his contemplation on cosmopolitanism has touched upon Kant and the concept of hospitality. He explained

\footnotetext{
11 Benhabib, S.; Rights of Others - Aliens, Residents, Citizens, Cambridge University Press, 2004. p. 49

12 Arendt, H.; The Origins of Totalitarianism, Harcourt, Brace, Jovanovich, 1973.

13 Benhabib, S.; Dignity in Adversity - Human Rights in Troubled Times, Verso, 2011.

14 Ibid. p. 30

15 Ibid. p. 30
} 
his views in the essay "On Cosmopolitanism" in which Derrida presents hospitality as one of the basic building blocks of ethics. In his opinion, "Hospitality is a culture itself and not simply one ethic amongst others. Insofar as it has to do with ethos, that is, the residence, one's home, the familiar place of dwelling, inasmuch as it is a manner of being there, the manner in which we relate to ourselves and others, the others as our own or as foreigners, ethics is hospitality; ethics is so thoroughly coextensive with the experience of hospitality". ${ }^{16}$

In the essay, Derrida's attention is on the concept of "the cities of refuge" as they have been known throughout the centuries, which is a practice of giving sanctuary to the migrants from the pressures of intimidation, persecution and exile. He traces this lineage to the Hebraic traditions of the Bible. For instance, the Book of Numbers states that God ordered Moses to institute cities which would be "the cities of refuge" or asylums, and to begin with, there should be six cities that would welcome and protect the innocents from "bloody vengeance".

Derrida tries to restore this old notion of "the cities of refuge" by going beyond the concept of hospitality, by proposing both a duty of hospitality and the right to hospitality. In these efforts, he called upon Hannah Arendt's analysis of the status of stateless and homeless people after two world wars. ${ }^{17}$ Arendt recognized two upheavals in that status - one was the progressive abolition of a right of asylum, and the other was the abandoning of naturalisation, both prompted by the massive influx of refugees after the wars. Derrida, drawing upon her insights asks "How can the right to asylum be redefined and developed without repatriation and without naturalisation? Could the City, equipped with new rights and greater sovereignty, open up new horizons of possibility previously undreamt of by international state law?" 18

Of course, in his reflections on the cosmopolitanism and hospitality Derrida had a precise intention - to critically address a concrete context, that is, France's relation towards "sans papiers" - unlawful residents. In addressing this issue, he located a double or contradictory imperative within the concept of cosmopolitanism. On one hand there is an unconditional hospitality that we should offer the right of refuge to all immigrants and newcomers, but on the other hand, hospitality must be conditional. Derrida is aware that unconditional hospitality is hard to achieve, but it still represents the desire behind the conditional hospitality that is necessary in our everyday dealings with others. He even notices that: "At the time when we claim to be lifting the internal borders, we proceed to bolt external borders of European Union tightly. Asylum-seekers knock successively on each of the doors of the European Union states and end up being repelled at each one of them. Under the pretext of

16 Derrida, J.; On Cosmopolitanism and Forgiveness, Routledge 2002. p.16

17 Arendt, H.; The Origins of Totalitarianism, Harcourt, Brace, Jovanovich, 1973.

18 Derrida, J.; On Cosmopolitanism and Forgiveness, Routledge 2002. p.7 
combating economic immigrants purporting to be exiles from political persecution, the states reject applications for the right to asylum more than ever." 19

Apparently, for Derrida all the political difficulty of immigration consists in negotiating between these two imperatives of conditional and unconditional hospitality. Finally, after identification of this contradictory logic at the heart of cosmopolitanism Derrida's solution for the hospitality is simple - "experience and experimentation thus". ${ }^{20} \mathrm{He}$ imagines that the experience of the cities of refuge will give rise to reflection on the questions of asylum and hospitality - and for a new order of law and democracy to come and to be put to the test.

\section{Conclusion}

What can we infer from the observations made earlier about hospitality for the times that lay ahead of us? Will the concept of hospitality be significantly changed after the pandemic? Will we live in more inhospitable times? If this overview is any indication, the loss will only be gradual, not total, as unconditional hospitality was always a mirage. Even in the Ancient Greece concept of hospitality was only applicable to higher classes, kings and heroes. Kant in his elaboration of cosmopolitan right evokes universal hospitality, but that hospitality also has its limits. Guests are only allowed visitation and initial contact, they do not have the right to settle or to force a commerce.

Both Benhabib and Derrida are less strict then Kant, but their thinking on hospitality also provides restrictions. Benhabib allows settlement of "guests", especially the ones that are fleeing some danger, whether that calamity is war or natural disaster, but on the question of economic migrations she leaves decisions up to the states to decide who they will admit inside their borders. Derrida is even less strict, especially in his endorsement of "cities of refuge", that is, the cities of unconditional hospitality, but he too is aware that this is only achievable (or at least he hopes that it is achievable) on small limited space under the auspices of the state.

Considering these accounts, we see that hospitality was never unconditional. Still, if the "new normal" will put new restrictions on us and our understanding of hospitality, it still does not mean that we should give up on an ideal. After all, unconditional hospitality might always be outside our reach, but just striving to reach it is probably something that is deeply ingrained into the human nature.

\section{References:}

1. Arendt, H.; The Origins of Totalitarianism, Harcourt, Brace, Jovanovich, 1973.

2. Aristotle; Politics, University of Chicago Press, 2013.

3. Benhabib, S.; Another Cosmopolitanism, Oxford University Press, 2006.

19 Ibid p. 13

20 Ibid p. 23 
4. Benhabib, S.; Dignity in Adversity - Human Rights in Troubled Times, Verso, 2011.

5. Benhabib, S.; Rights of Others - Aliens, Residents, Citizens, Cambridge University Press, 2004.

6. Derrida, J.; On Cosmopolitanism and Forgiveness, Routledge 2002.

7. Diogenes Laertius; Lives of Eminent Philosophers, Oxford University Press, 2018.

8. Herman, G.; Ritualised Friendship \& the Greek City, Cambridge University Press, 1987.

9. Kant, I.; Political Writings, Cambridge University Press, 1991. 